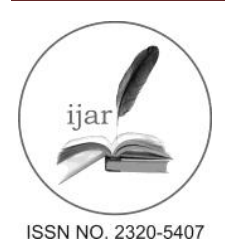

Journal homepage:http://www.journalijar.com
Journal DOI:10.21474/IJAR01

RESEARCH ARTICLE

\title{
ASSESSMENT OF CONTAMINATION BY HEAVY METALS IN SOIL OF LAYLAN AREA / NE OF IRAQ.
}

\author{
Hisham K. M.Shukur ${ }^{1}$ and Omer S.Al-Tamimi ${ }^{2}$. \\ 1. Master Student at Dept. of Applied Geology, College of Science, Kirkuk University. \\ 2. Environmental Research center,College of Science, University of Kirkuk, Kirkuk,Iraq.
}

\section{Manuscript Info}

Manuscript History:

Received: 18 May 2016

Final Accepted: 19 June 2016

Published Online: July 2016

Keywords:

Metalloids (heavy

metals),Laylansub-district,

Contamination Factor, Geo-

accumulation Index, pollution load

Index, andEnrichment Factor.

*Corresponding Author

Hisham K. M.Shukur.

\section{Abstract}

The metal contamination in soil ofLaylansub-districtwas evaluated by applying Geo-accumulation Index (I-geo),Enrichment Factor (EF), Contamination Factor (CF), Degree ofContamination (Cd) and Pollution Load Index (PLI) fortenmetalloids(heavy metals) elements ( $\mathrm{Se}, \mathrm{As}, \mathrm{Cd}, \mathrm{Ni}$, $\mathrm{ZN}, \mathrm{Cr}, \mathrm{Pb}, \mathrm{Ag}, \mathrm{Cu}, \mathrm{Hg}$ ). According to the calculated of Contamination factor $(\mathrm{CF})$ values, the mean $\mathrm{CF}$ values for different heavy metals in the soil of Laylan are $\mathrm{Se}>\mathrm{As}>\mathrm{Cd}>\mathrm{Ni}>\mathrm{ZN}>\mathrm{Cr}>\mathrm{Pb}>\mathrm{Ag}>\mathrm{Cu}>\mathrm{Hg}$. Soil site No. 4 recorded the maximum value of the degree of contamination which indicated as aconsiderable degree of contamination. Site 5 displayed the highestPLI value $=0.968$. Based onGeo-accumulation Index I-geoof laylan soil the mean value of I-geo for metalloids(heavy metals) elementsas the following order: $\mathrm{Se}>\mathrm{As}>\mathrm{Cd}>\mathrm{Ni}>\mathrm{ZN}>\mathrm{Cr}>\mathrm{Pb}>\mathrm{Ag}>\mathrm{Cu}>\mathrm{Hg}$. According to enrichment factorthe meanvalues of EF for heavy metals have an order $\mathrm{Se}>$ $\mathrm{As}>\mathrm{Cd}>\mathrm{Ni}>\mathrm{ZN}>\mathrm{Cr}>\mathrm{Pb}>\mathrm{Ag}>\mathrm{Cu}>\mathrm{Hg}$.

Copy Right, IJAR, 2013,. All rights reserved

\section{Introduction:-}

Metals are natural constituents in nature. In fact, during the last few decades, industrial and urban activities have contributed to the increase of metals contamination. The pollution of heavy metals is an important cause of soil destruction. The danger of heavy metals, unlike other pollutants, lies in their being non-degradable and the accumulation in the earth's surface (Harikumar et al 2007). Pollution of the natural environment by heavy metals is a worldwide problem because these metals are permanent and most of them have toxic effects on living organisms when they exceed a certain concentration (Chakraborty, R., Zaman, S., Mukhopadhyay, N., Banerjee, K., and Mitra, A. 2009). The metal toxicity is usually defined in terms of the concentration required to cause an acute response (usually death) or a sub-lethal response (Smith, D.G. 1986).Heavy metal pollutants pose potential threats to ecosystems because they could be concentrated or accumulated in organisms and biomagnified at higher trophic levels (Gao and Chen, 2012). Heavy metal contamination of soils is regarded as a potential hazard to food safety and public health. Exposure to polluted soils may take place in different ways such as through the consumption of vegetables grown on contaminated soils, drainage of rich in heavy metals waste disposal, dust inhalation (Christos G. Karydas et al, water 2015). The soil is the mixture of minerals, organic matter, gasses, liquids, and the countless organisms that together support life on Earth.Soil may go through anatural stage of building, sustaining, and degrading. Each stage has important implication for theecosystem. Since many soil properties are interrelated with one another, it is difficult to draw distinct lines of division where one type of Property dominates the behavior of the soil (Edward A. Keller 2005). Therefore, understanding and recognizing soil properties and their connections with one another is important for making sound decisions regarding soil use and management. Laylan area is selected for this study due to exposure to thehigh amount of environment impact fromdifferent sources like air pollution from variation type of factory and industry (Kirkuk cement factory, Quarries of rocks) which producealot of pollutants and dust. And this material deposed on the land addition to that exists on the land by different source such pollutants that exists due to land use, agriculture land using fertilizer for flora growing, and using pesticides to eliminate the harmful creature that effected on the crops this stuff of materials settle down on the soil and change the chemical 
and physical properties of the soil and making degradation of soil and this material uptake by flora and the food chain becomes degradation.

\section{Methodologies:-}

\section{Study area:-}

The study area (Laylan) located in the northeastern part of Iraq,itis a sub-district belongs to Kirkuk province. Laylan is approximately $26 \mathrm{Km}$ to the southeast of the governorate capital, Kirkuk. Geographically, the area of study lies in between latitudes $\left(35^{\circ} 21^{\prime}-35^{\circ} 12^{\prime}\right)$, and longitudes $\left(44^{\circ} 35^{\prime}-44^{\circ} 20^{\prime}\right)$, the area of study is about $250 \mathrm{~km}^{2}$. It's boundedTaza sub-district from thewest, KhaloBaziani sub-district from east and Tawuq district from thesouthwest, these places belong Kirkuk province. Geologically, structural boundaries for the study area from east and northeast by Kirkuk anticline, while in the west and southwest by Jambur Mountains (Anticline), and it is bounded by hydrological natural boundaries from north and northwest by ephemeral stream (intermittent stream named Shireen valley), while in the south and southwest by ephemeral stream named Mamsha valley.

Figure 1:- Map showing soil sampling locations.

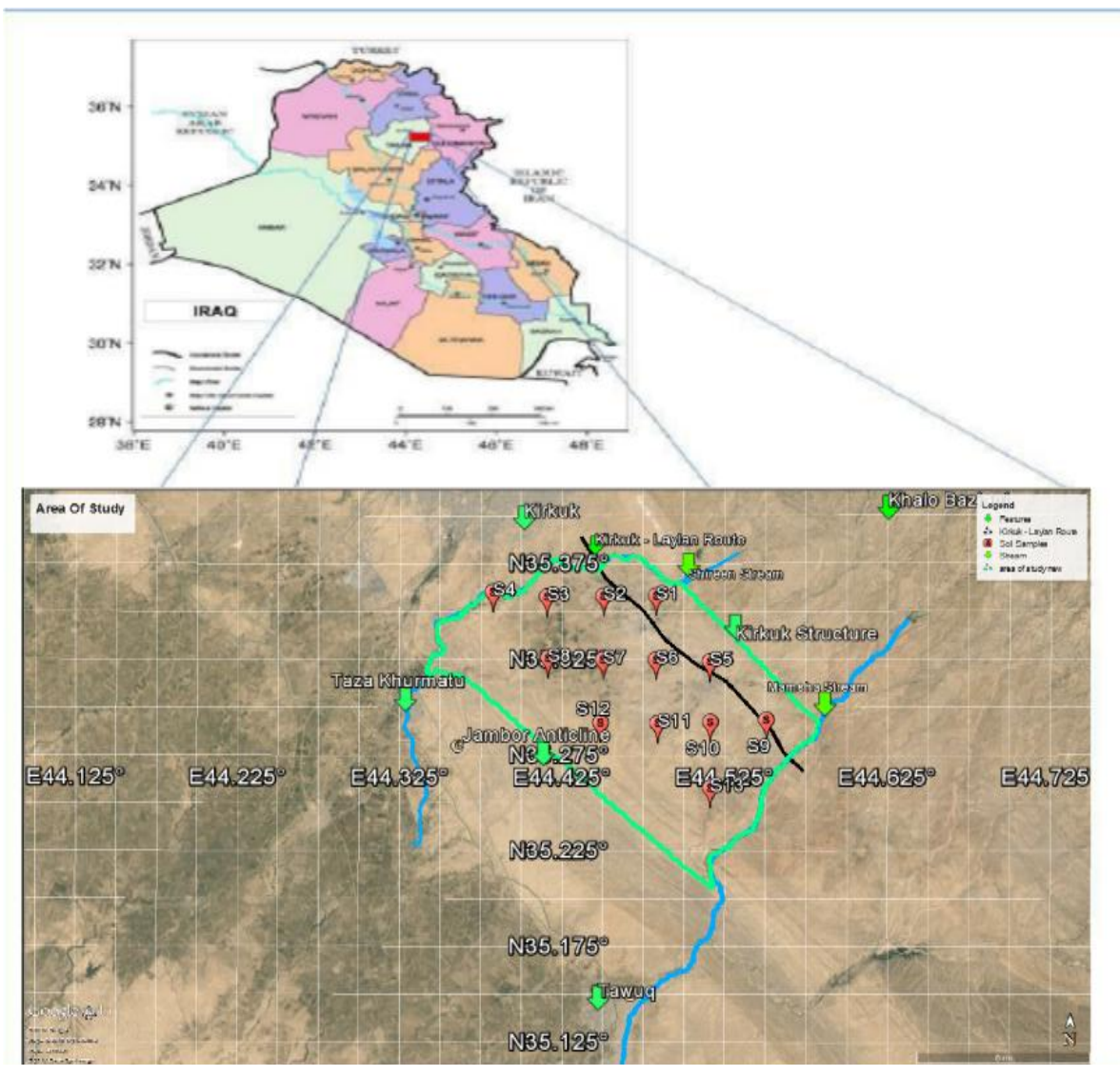

\section{Sample collection, preparation:-}

The samplewas taken in awet season (March 2014) from thirteen stations of Laylanarea and characterized by (S1 S13) (in the map represented by Red placemark).For aselection of the sampling grid(sample density) for this group, we depend on (Salminen, 1992). The method that used for samples location across the area of study is alocal phase, i.e. our Sampling density is sample sites per $11.2 \mathrm{~km}^{2}$ ). For sampling network, we use the most useful sample network which is a regularly irregular grid. The study area is first divided into cells of equal size and shape according to the selected sampling density. The actual sampling site is then selected inside the cell to represent the whole cell area as best as possible. In this case, the preliminary planning is done at the office, but the actual sampling site is defined in the field.Each soil sample was a composite of five subsamples collected from pits located at a distance of 10-20 m from each other. Samples were taken at depth $25 \mathrm{~cm}$. Living surface vegetation, fresh litter, large roots, and rock fragments (stones) were removed by hand.The soil sample was quickly packed in air tight 
polythene bags. After air drying, samples were passed through a $2 \mathrm{~mm}$ sieve to remove large debris, stones, and pebbles, and then they were stored in plastic containers and sent to Acme lab in Vancouver/Canada for analyzing the elements by ICP-MS.

\section{Results and Discussion:-}

Indices to assessment of Metal Contamination:-

Several indices were used to assess the metal contamination levels in the sediment samples, namely Contamination Factor (CF), Degree of Contamination $\left(\mathrm{C}_{\mathrm{d}}\right)$, Enrichment Factors (EF), Geo-accumulation index (I-geo) and Pollution Load Index (PLI), World surface rock average data of heavy metals which were used as background values were taken from (Jefferson Lab 2007).

\section{Contamination factor and degree of contamination:-}

Generally, sediments have been used as environmental indicators, and this ability to identify heavy metal contamination sources and monitor contaminants is also well documented. The contamination factor $\mathrm{CF}$ and the degree of contamination were used to determine the contamination status of the sediment in the present study. Thus, the accumulation of metals in the sediments is strongly controlled by the nature of the substrate as well as the physicochemical conditions controlling dissolution and precipitation (Venkatramanan, S., et al, 2012). The contamination factor $\mathrm{CF}$ and the degree of contamination were used to determine the contamination status of the sediment in the present study. CF was calculated according to the equation described below

$$
\boldsymbol{C F}=\boldsymbol{M c} / \boldsymbol{B C}
$$

Where Mc Measured concentration of the metal and $\mathrm{Bc}$ is the backgroundconcentration of the same metal (Table 1). Four contamination categories are documented on the basis of the contamination factor (Hakanson, L. 1980). CF $<1$ low contamination; $1 \leq \mathrm{CF}<3$ moderate contamination; $3 \leq \mathrm{CF}<6$ considerable contamination; $\mathrm{CF}>6$ very high contamination, while the degree of contamination $(\mathrm{Cd})$ was defined as the sum of all contamination factors. The following terminology was adopted to describe the degree of contamination (Cd values) for the selected ten metals. $\mathrm{Cd}<6$ : low degree of contamination; $6 \leq \mathrm{Cd}<12$ : amoderate degree of contamination; $12 \leq \mathrm{Cd}<24$ : considerable degree of contamination; $\mathrm{Cd}>24$ : very high degree of contamination indicating serious anthropogenic pollution.

The average $\mathrm{CF}$ values for different heavy metals in the soil of Laylan are $\mathrm{Se}>\mathrm{As}>\mathrm{Cd}>\mathrm{Ni}>\mathrm{ZN}>\mathrm{Cr}>\mathrm{Pb}>\mathrm{Ag}>\mathrm{Cu}>$ $\mathrm{Hg}$ (Table2). The maximum value of contamination factor for selenium was noticed in soil at site No. 4 which equals to14, which indicating that this environment isvery high contamination, while the minimum CF was recorded for mercuryin Soil site No. 9which equals to0.106 asin (Table2). While average CF forAs and Cd, Niindicating as moderate contamination. In contrast, the rest of the heavy metals exhibit as low contamination in general. Furthermore, the highest degrees of contamination were observed in soil site4 which indicating moderate degrees of contamination.Soil site No.4, 8 and 11 had Very high contaminationbySelenium, while the Soil site No. 1, 2, 3, 4, 5, 6, 7, 8, 9, 10, 12recorded Considerable contamination with Arsenic and Selenium. AllSoilsites in the current study recorded low contamination factor for $\mathrm{Zn}, \mathrm{Cu}, \mathrm{Cr}, \mathrm{Pb}, \mathrm{Hg}$, and $\mathrm{Ag}$. Moderate contamination for $\mathrm{Cd}$ and $\mathrm{Ni}$ was recorded for all soil sites. Soil site No. 4 recorded the maximum value of the degree of contamination while Soil Site No.9, 10 and 13 recorded the lowest value for thedegree of contamination as illustrated in (Table 2).

\section{Pollution Load Index:-}

Pollution Load Index (PLI) was used to evaluate the extent of pollution by heavy metals in the environment.

$$
P L I=(C F 1 \times C F 2 \times C F 3 \times \ldots \ldots \ldots F n) 1 / n
$$

The values of PLI > 1 imply that heavy metal pollution exists. Otherwise, if PLI $<1$, there is no heavy metal pollution (Tomlinson et al., 1980). The range and class are same as I geo.The value of PLI in all sites is lower than 1 as in (Table 2) which consider as no heavy metal pollution 
Table 1:- Background concentration of heavy metals (in $\mathrm{mg} / \mathrm{kg}$ ) in the crust of earth (Jefferson Lab, 2007)

\begin{tabular}{|l|l|l|l|l|l|l|l|l|l|l|}
\hline Metals & $\mathrm{Zn}$ & $\mathrm{Cu}$ & $\mathrm{Pb}$ & $\mathrm{Cd}$ & $\mathrm{Ni}$ & $\mathrm{Cr}$ & $\mathrm{Hg}$ & $\mathrm{As}$ & $\mathrm{Se}$ & $\mathrm{Ag}$ \\
\hline $\begin{array}{l}\text { background } \\
\text { concentration of } \\
\text { the metal (ppm) }\end{array}$ & 70 & 60 & 14 & 0.15 & 84 & 102 & 85 & 1.8 & 0.05 & 0.075 \\
\hline
\end{tabular}

Table 2: Contamination Factor (CF), Degree of Contamination (Cd) and pollution Load Index(PLI) of soil samples collected from Laylan area.

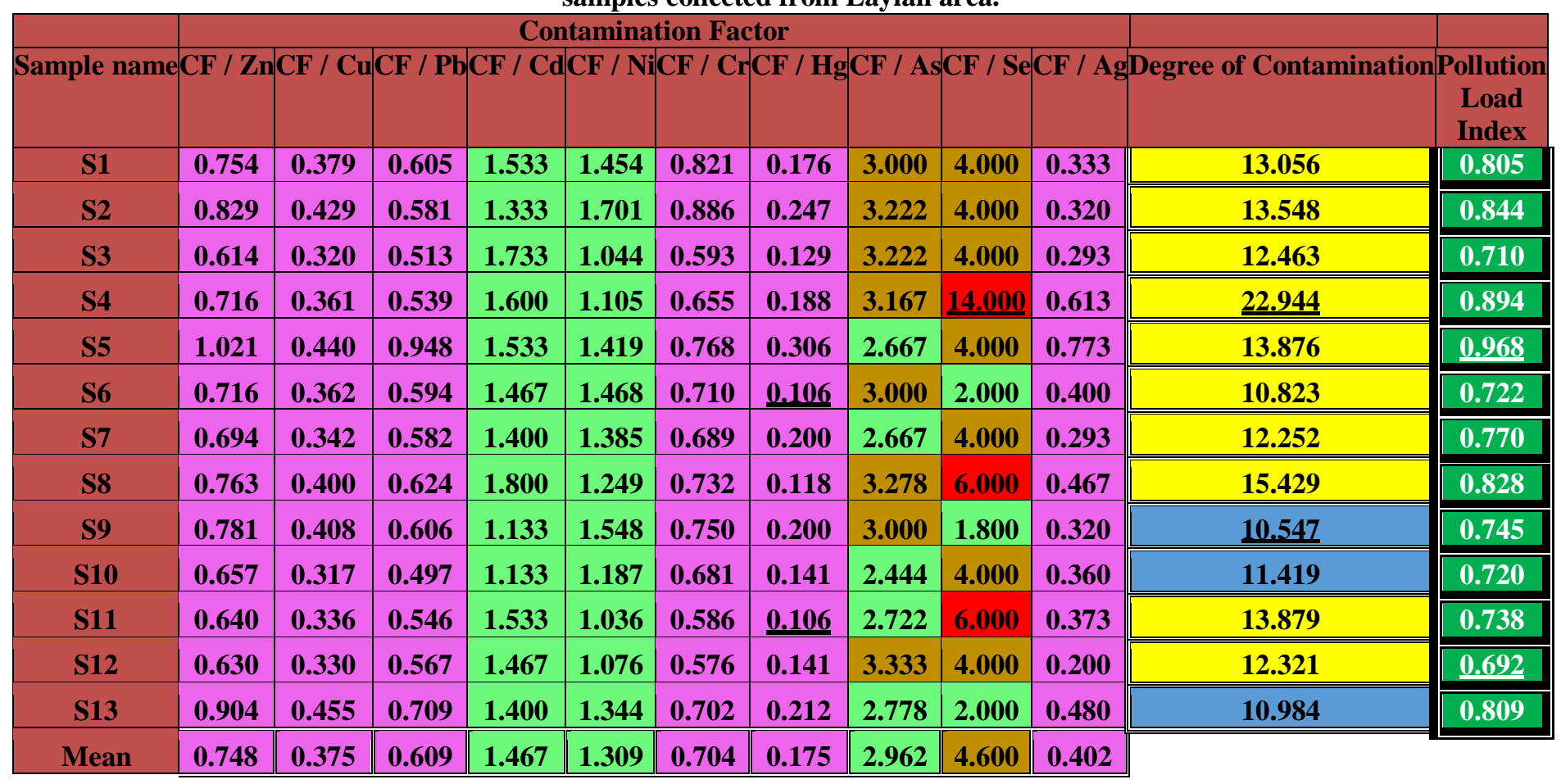

\begin{tabular}{|l|l|}
\hline Cell Paint in Table No. & \multicolumn{1}{|c|}{ Contamination Factor categories } \\
\hline & $\mathrm{CF}<1$ (Low contamination) \\
\hline & $1 \leq \mathrm{CF}<3$ (Moderate contamination) \\
\hline & $3 \leq \mathrm{CF}<6$ (Considerable contamination) \\
\hline & $\mathrm{CF}>6$ (Very high contamination) \\
\hline
\end{tabular}

\begin{tabular}{||c||c||}
\hline \hline Cell Paint in Table No. & Degree of Contaminationcategories \\
\hline \hline \hline & $6 \leq \mathrm{Cd}<12$ (Moderate degree of contamination) \\
\hline \hline
\end{tabular}


Figure 2:- Variation of Contamination Factor (CF) values of heavy metals (Metalloids) in soil sites from Laylan area.

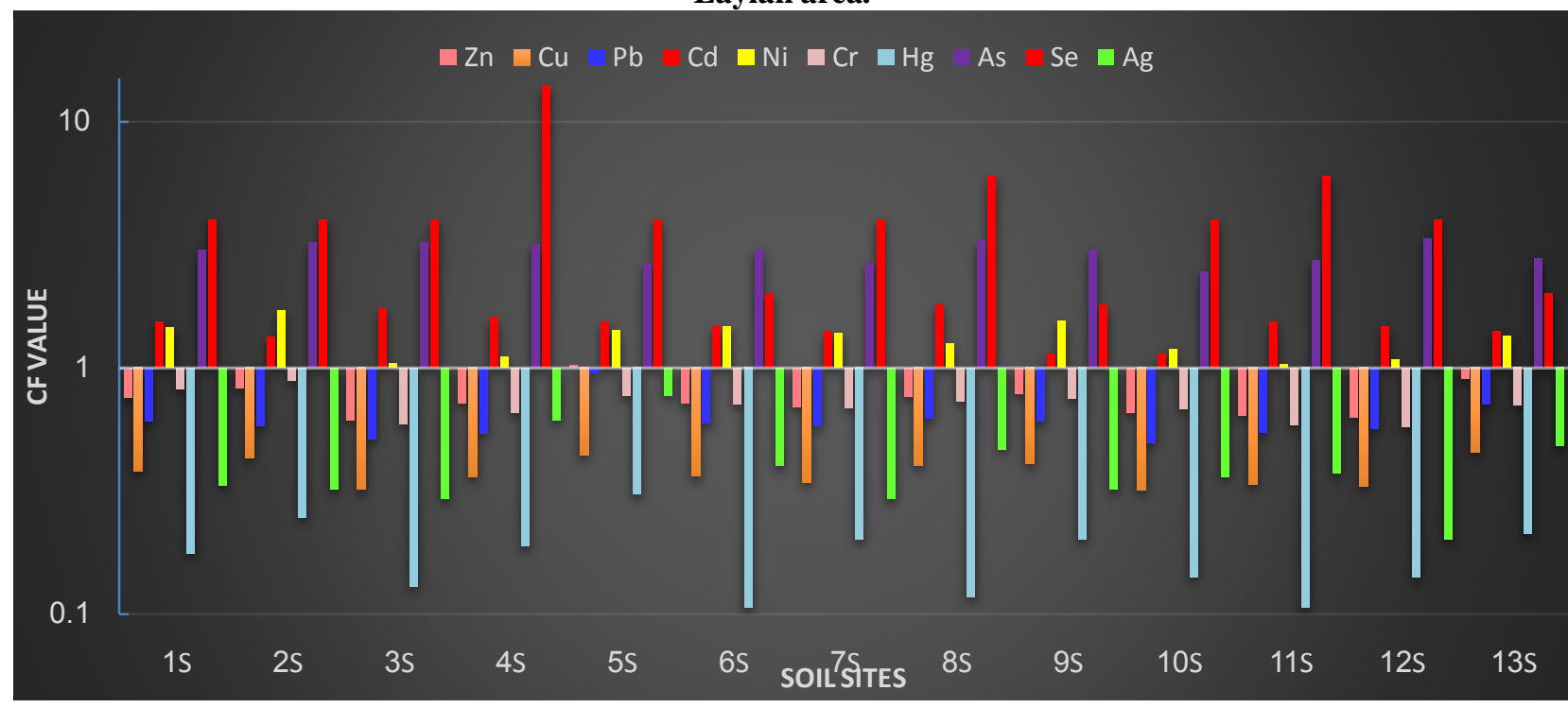

\section{Enrichment factor:-}

The enrichment factor is the relative abundance of a chemical element in a soil compared to the bedrock (Hernande, et al 2003). EF was calculated by a comparison of each tested metal concentration with that of a reference metal (Muller, G. 1981). The normally used reference metals are Mn, Al, and Fe (Liu, 2005).In this study iron was used to keep differences between natural from anthropogenic components, according to the hypothesis which quotethe contentcomponents in the earth crust have not been troubled ordisturbed by anthropogenic activity affect and it has been chosen as the element of normalization because natural sources and natural process is approximated equal to (98\%) of theall process that the earth evolved, so the natural sources greatly dominate its contribution (Tippie, V.K. 1984). According to Rubio et al. (Rubio, et al, 2000). The EF is defined as follows:

$$
E F=\left(\frac{M}{F E}\right) \text { Sample } /\left(\frac{M}{F E}\right) \text { background }
$$

Where $\mathrm{EF}$ is the enrichment factor, $(\mathrm{M} / \mathrm{Fe})$ sample is the ratio of metal and $\mathrm{Fe}$ concentration of the sample and $(\mathrm{M} / \mathrm{Fe})$ background is the ratio of metals and $\mathrm{Fe}$ concentration of a background. Five contamination categories are reported on the basis of the enrichment factor (Sutherland, R.A, 2000). EF $<2$ deficiency to minimal enrichment, $\mathrm{EF}=2-5$ moderate enrichment, $\mathrm{EF}=5-20$ significant enrichment, $\mathrm{EF}=20-40$ very high enrichment, $\mathrm{EF}>40$ extremely high enrichment. As shown in (Table 3). Average EF values for heavy metals have an order $\mathrm{Se}>\mathrm{As} \mathrm{Cd}>$ $\mathrm{Ni}>\mathrm{ZN}>\mathrm{Cr}>\mathrm{Pb}>\mathrm{Ag}>\mathrm{Cu}>\mathrm{Hg}$, suggesting that soil samples was significant enrichment with $\mathrm{Se}$ and As, while $\mathrm{Cd}$ exhibit moderate enrichment, and $\mathrm{Zn}$ exhibit as moderate enrichment. The rest of the metals show minimal enrichment in the study area.

According to enrichment factor, the highest $\mathrm{EF}$ value is in soil site No. 4 for $\mathrm{Se}=44.034$ which indicated as significant enrichment, while the lowest EF value is in soil site No. 8 for $\mathrm{Hg}=0.304$ which indicated deficiency to minimal enrichment. 
Table 3: Enrichment Factor (EF) for the soil samples of the Laylan area.

\begin{tabular}{|c|c|c|c|c|c|c|c|c|c|c|}
\hline & \multicolumn{10}{|c|}{ Enrichment Factor } \\
\hline $\begin{array}{c}\text { Sample } \\
\text { name }\end{array}$ & $\mathrm{Zn}$ & $\mathbf{C u}$ & $\mathbf{P b}$ & Cd & $\mathbf{N i}$ & $\mathrm{Cr}$ & Hg & As & Se & Ag \\
\hline S1 & 1.896 & 0.953 & 1.521 & $\mathbf{3 . 8 5 4}$ & 3.653 & 2.062 & 0.444 & 7.540 & 10.054 & 0.838 \\
\hline S2 & 1.968 & 1.018 & 1.380 & 3.167 & 4.041 & 2.105 & 0.587 & 7.654 & 9.502 & 0.760 \\
\hline S3 & 1.756 & 0.915 & 1.466 & 4.954 & 2.984 & 1.695 & 0.370 & 9.209 & 11.431 & 0.838 \\
\hline S4 & 2.251 & 1.135 & 1.696 & 5.032 & $\mathbf{3 . 4 7 5}$ & 2.060 & 0.592 & 9.960 & 44.034 & 1.929 \\
\hline S5 & 2.752 & 1.186 & 2.553 & 4.130 & 3.823 & 2.068 & 0.824 & 7.183 & 10.775 & 2.083 \\
\hline S6 & 1.919 & 0.971 & 1.593 & 3.932 & 3.935 & 1.903 & 0.284 & 8.043 & 5.362 & 1.072 \\
\hline S7 & 1.945 & 0.957 & 1.631 & 3.921 & 3.878 & 1.930 & 0.560 & 7.469 & 11.204 & 0.822 \\
\hline S8 & 1.970 & 1.032 & 1.610 & 4.649 & 3.225 & 1.891 & 0.304 & 8.465 & 15.495 & 1.205 \\
\hline S9 & 1.913 & 0.998 & 1.484 & 2.774 & 3.788 & 1.836 & 0.490 & 7.343 & 4.406 & 0.783 \\
\hline S10 & 1.888 & 0.911 & 1.428 & 3.255 & 3.409 & 1.957 & 0.406 & 7.022 & 11.490 & 1.034 \\
\hline S11 & 1.775 & 0.933 & 1.513 & 4.253 & 2.872 & 1.626 & 0.294 & 7.550 & 16.640 & 1.035 \\
\hline S12 & 1.867 & 0.979 & 1.681 & 4.346 & 3.189 & 1.708 & 0.418 & 9.877 & 11.853 & 0.593 \\
\hline $\mathrm{S13}$ & 2.533 & 1.275 & 1.985 & 3.921 & 3.765 & 1.966 & 0.593 & 7.781 & 5.602 & 1.344 \\
\hline Mean & 2.033 & 1.020 & 1.657 & 4.015 & 3.541 & 1.908 & 0.474 & 8.084 & 12.911 & 1.103 \\
\hline
\end{tabular}

\begin{tabular}{|l|l|}
\hline \multicolumn{1}{|c|}{ Cell Paint in Table No. } & \multicolumn{1}{|c|}{ Enrichment Factor categories } \\
\hline & $\mathrm{EF}<2$ (Deficiency to minimal enrichment) \\
\hline & $\mathrm{EF}=2-5$ (Moderate enrichment) \\
\hline & $\mathrm{EF}=5-20$ (Significant enrichment) \\
\hline
\end{tabular}

Figure 3:- Variation of Enrichment Factor (EF) values of heavy metals in soil sites from Laylan area.

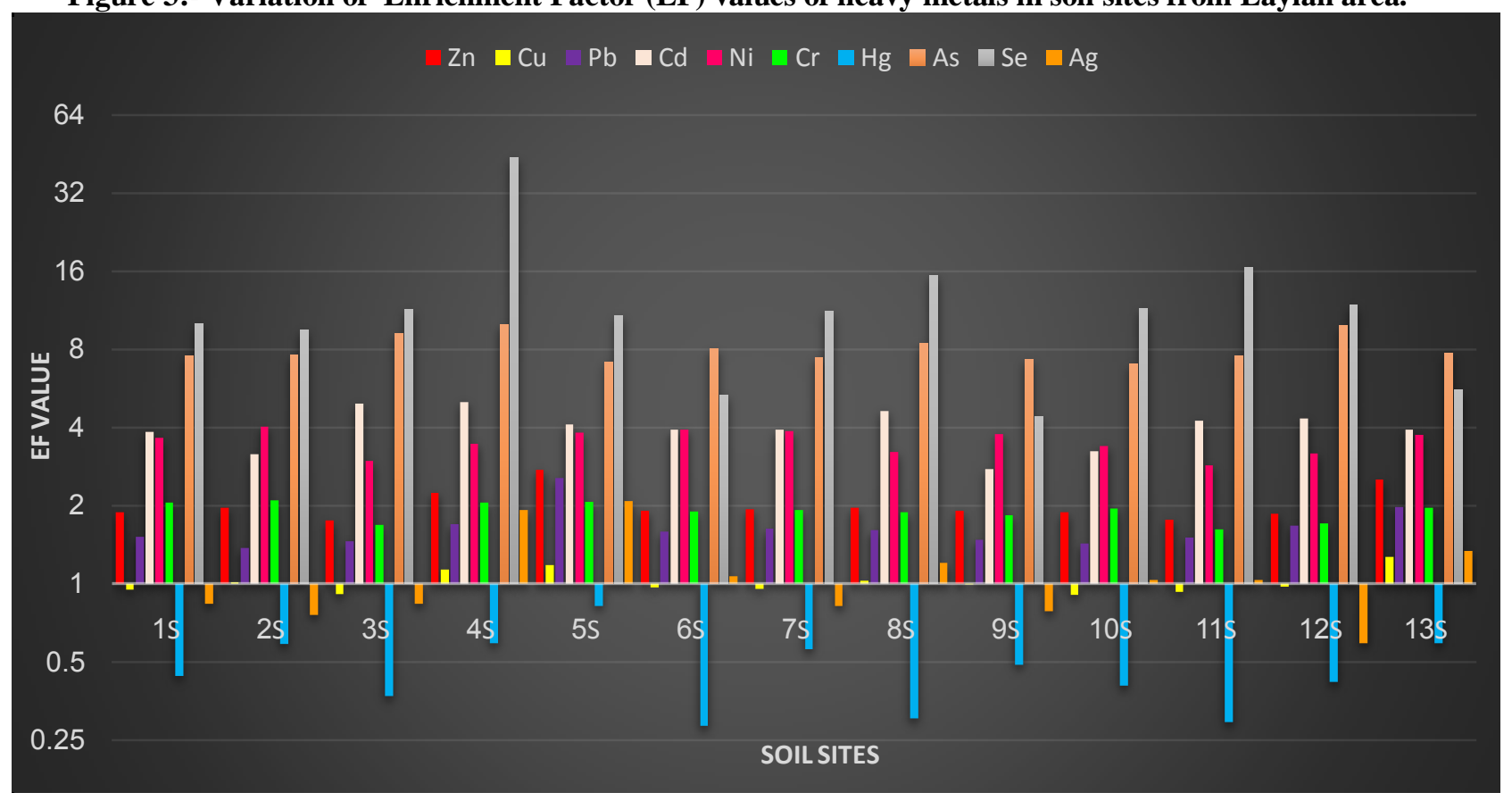

Geo-accumulation Index:-

Geo-accumulation index (I-geo) was employed to evaluate the heavy metals pollution in the soil of Laylan area. This method has been used by Müller (Müller, G. 1969).I-geo was calculated using the following equation:

$$
I-g e o=\log 2 /(C n / 1.5 B n)
$$


Where $\mathrm{Cn}$ is the measured content of the examined metal in the sediment samples and $\mathrm{Bn}$ is the geochemical background content of the same metal.Factor 1.5 is the background matrix correction factor due to Lithogeny effects.This factor is introduced to minimize the effect of possible variations in the background values, which may be recognized to anthropogenic influences. The following classification is given by (Muller, 1981) has distinguished seven classes of Geo-accumulation index I-geo: $<0=$ practically unpolluted, $0-1=$ unpolluted to moderately polluted, 1-2 = moderately polluted, 2-3 =moderately to strongly polluted, 3-4 = strongly polluted, $4-5=$ strongly to extremely polluted, and $>5=$ extremely polluted (Müller, G., 1969). The calculated results of I-geo (Table).

Assessment According to Geo-accumulationIndex all soil site are unpolluted for $\mathrm{Zn}, \mathrm{Cu}, \mathrm{Cr}$. $\mathrm{Hg}, \mathrm{Ag}, \mathrm{Pb}$ and $\mathrm{Ni}$ except S9 whichis unpolluted tomoderately pollute with $\mathrm{Ni}$. S1, S3, S4, S5, S8, S11 are unpolluted to moderately polluted with Cd. S5, S7, S10, S11, and S13 are unpolluted to moderately polluted with As. The maximum value of Geo-accumulation index (I-geo) are in S4 for Se $=3.222$ which indicated as strongly polluted with Selenium, andthe minimum value of Geo-accumulation index (I-geo) are in S6 and S11 for $\mathrm{Hg}=3.222$.Moderately pollutedwith $\mathrm{Se}$ for soil site S1, S2, S3, S5, S7, S10, S12 and moderately to strongly polluted with Se for S8 and S11. The variation of Geo-accumulation index of the Soil samples was shown in (Table 4). On the basis of the mean values of I-geo indicate that Se considered to be a moderately polluted, while the rest I-geo means values of the metals show practically unpolluted degree in the study area, the mean value of I-geo for metals as the following order: $\mathrm{Se}>\mathrm{As}>$ $\mathrm{Cd}>\mathrm{Ni}>\mathrm{ZN}>\mathrm{Cr}>\mathrm{Pb}>\mathrm{Ag}>\mathrm{Cu}>\mathrm{Hg}$.

Table 4:- Geo-accumulation Index (I-geo values) of heavy metals in soil from Laylan area.

\begin{tabular}{|c|c|c|c|c|c|c|c|c|c|c|}
\hline & \multicolumn{10}{|c|}{ Geo-accumulation Index (I-geo) } \\
\hline $\begin{array}{c}\text { Sampl } \\
\text { e } \\
\text { name }\end{array}$ & $\mathbf{Z n}$ & $\mathbf{C u}$ & $\mathbf{P b}$ & $\mathrm{Cd}$ & $\mathbf{N i}$ & $\mathrm{Cr}$ & $\mathrm{Hg}$ & $\overline{A s}$ & $\mathrm{Se}$ & $\mathbf{A g}$ \\
\hline S1 & -0.992 & -1.983 & -1.310 & 0.032 & -0.045 & -0.870 & -3.087 & 1.000 & 1.415 & -2.170 \\
\hline S2 & -0.856 & -1.807 & -1.369 & -0.170 & 0.182 & $\begin{array}{l}-0.759 \\
\end{array}$ & -2.602 & 1.103 & 1.415 & -2.229 \\
\hline S3 & -1.288 & -2.229 & -1.548 & 0.209 & -0.523 & -1.339 & -3.535 & 1.103 & 1.415 & -2.354 \\
\hline S4 & -1.068 & -2.055 & -1.476 & 0.093 & -0.441 & -1.196 & -2.994 & 1.078 & 3.222 & -1.290 \\
\hline S5 & -0.554 & $\begin{array}{c}.768 \\
\end{array}$ & -0.662 & 0.032 & $\begin{array}{c}-0.080 \\
\end{array}$ & -0.966 & -2.294 & 0.830 & 1.415 & -0.956 \\
\hline S6 & -1.068 & -2.050 & -1.336 & -0.032 & 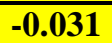 & $\begin{array}{c}-1.079 \\
\end{array}$ & -3.824 & 1.000 & 0.415 & -1.907 \\
\hline S7 & -1.111 & -2.135 & -1.366 & -0.100 & -0.116 & -1.122 & -2.907 & $\overline{0.830}$ & 1.415 & -2.354 \\
\hline S8 & -0.975 & -1.908 & -1.266 & 0.263 & -0.264 & -1.034 & -3.672 & 1.128 & 2.000 & -1.685 \\
\hline S9 & -0.941 & -1.879 & -1.307 & -0.404 & 0.045 & -1.000 & -2.907 & 1.000 & 0.263 & -2.229 \\
\hline S10 & -1.191 & -2.242 & -1.593 & -0.404 & -0.338 & -1.138 & -3.409 & $\overline{0.705}$ & 1.415 & -2.059 \\
\hline S11 & -1.229 & -2.157 & -1.459 & 0.032 & -0.534 & -1.355 & -3.824 & 0.860 & 2.000 & -2.006 \\
\hline S12 & -1.252 & -2.183 & -1.403 & -0.032 & -0.479 & -1.380 & -3.409 & 1.152 & 1.415 & -2.907 \\
\hline S13 & -0.730 & -1.721 & -1.082 & -0.100 & -0.158 & -1.096 & -2.824 & 0.889 & 0.415 & -1.644 \\
\hline Mean & -1.020 & -2.009 & -1.321 & -0.045 & -0.214 & -1.103 & -3.176 & 0.975 & 1.402 & -1.984 \\
\hline
\end{tabular}

\begin{tabular}{|c|c|}
\hline Cell Paint in Table No. & Geo-accumulation index (I-geo) \\
\hline & $<0=$ practically unpolluted \\
\hline & $0-1=$ unpolluted to moderately polluted \\
\hline & $1-2=$ moderately polluted \\
\hline & $2-3=$ moderately to strongly polluted \\
\hline & $3-4=$ strongly polluted \\
\hline
\end{tabular}


Figure 4:- Variation ofGeo-accumulation Index(I-geo)values of heavy metals in soil sites from Laylan area.

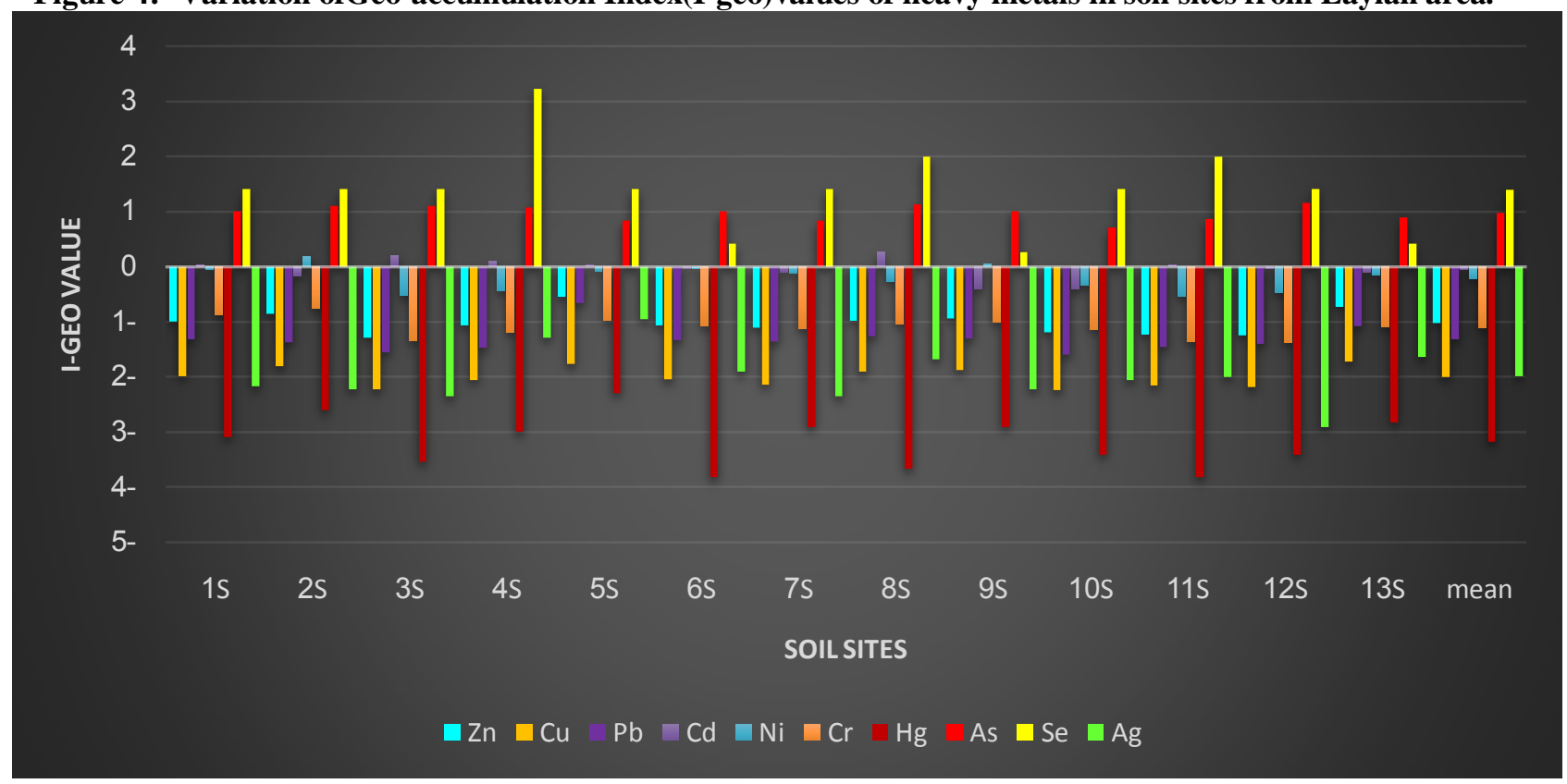

\section{Reference:-}

1. Chakraborty, R., Zaman, S., Mukhopadhyay, N., Banerjee, K., and Mitra, A. (2009). Seasonal Variation of Zn, $\mathrm{Cu}$, and $\mathrm{Pb}$ in the Estuarine Stretch of West Bengal, Indian Journal of Marine Science, 38(1), 104-109.

2. Christos G. Karydas 1 et al. (2015). A New Spatiotemporal Risk Index for Heavy Metals:Application in Cyprus, School of Agriculture Forestry and Natural Environment, Aristotle University of Thessaloniki, Epanomi 57500, Greece; School of the Environment, University of the Aegean, Mytilini 81100, Greece; European Commission, Joint Research Centre, Institute for Environment and Sustainability, Ispra (Varese) IT 21027, Italy, Journal of water 2015, 7, 4323-4342.

3. Edward A. Keller (2008). Introduction to Environmental Geology, Pearson Education, Inc. 3, 528-549.

4. Gao X, Chen CTA. 2012. Heavy metal pollution status in surface sediments of the coastal Bohai Bay. Water Resources, 46: 1901-1911

5. Hakanson, L. (1980). An Ecological Risk Index for Aquatic Pollution Control a Sedimentological Approaches, Water Research, 14(8), 975-1001.

6. Hernande, Z.L. Probst, A., Probst, J.L., Ulrich, E. (2003). Heavy Metal distribution in some French Forest soils: Evidence for Atmosphere contamination. The science of total environment; 312:195-210.

7. Jefferson Lab. its Elemental - the Periodic Table of Elements. Archived from the original on 29 April 2007. Retrieved 2007-04-14.

8. Liu, W-H., Zhao, J-Z., Ouyang, Z-Y., Söderlund, L. and Liu, G-H. (2005). Impacts of Sewage Irrigation on Heavy Metal Distribution and Contamination in Beijing, China, Environmental International, 31(6), 805-812.

9. Muller, G. (1981). The Heavy Metal Pollution of the Sediments of Neckar and Its Tributary, a Stocktaking ChemischeZeit, 150, 157-164.

10. Müller, G. (1969). Index of Geo-accumulation in Sediments of the Rhine River, Geojournal2 (3), $108-118$.

11. Rubio, R. and Vilas, F. (2000). Geochemistry of Major and Trace Elements in Sediments of the Ria de Vigo (NW Spain) an Assessment of Metal Pollution, Marine Pollution Bulletin, 40(11), 968-980.

12. Smith, D.G. (1986). Heavy Metals in the New Zealand Aquatic Environment: A Review, Water Quality Centre, Ministry of Works and Development, Wellington, New Zealand.

13. Sutherland, R.A. (2000). Bed Sediment-Associated Trace Metals in an Urban Stream, Oahu, Hawaii, Environmental Geology, 39(6), 611-627.

14. Tippie, V.K. (1984). An Environmental Characterization of the Chesapeake Bay and a Frame Work for Action, In V. Kennedy, Ed., The Estuary as a Filter, Academic Press, New York, 1984.

15. Venkatramanan, S., Ramkumar, T., Anithamary, I. and Vasudevan, S. (2012). Heavy Metal Distribution in Surface Sediments of the Tirumalairajan River Estuary and the Surrounding Coastal Area, East Coast of India, Arabian Journal of Geosciences, 7(1), 123-130. 